\title{
Effect of replacement of de-oiled rice bran with sweet potato leaf meal on growth performance, digestive enzyme activity and body composition of Labeo rohita (Hamilton, 1822)
}

\author{
ZISHAN AHMAD, ASHUTOSH DHARMENDRA DEO, SARVENDRA KUMAR*, \\ AMIT RANJAN, Md. AKLAKUR AND NAROTTAM PRASAD SAHU \\ ICAR-Central Institute of Fisheries Education, Versova, Mumbai - 400 061, Maharashtra, India \\ ${ }^{*}$ College of Fisheries Science Gumla, Birsa Agricultural University, Ranchi - 834 006, Jharkhand, India \\ e-mail: ashutoshddeo@gmail.com; ashutosh@cife.edu.in
}

\section{ABSTRACT}

\begin{abstract}
A 60-days feeding experiment was conducted to evaluate the utilisation of sweet potato leaf meal (SPLM) for replacement of de-oiled rice bran (DORB) in the diets of rohu Labeo rohita (Hamilton, 1822) fingerlings. SPLM has good protein content $(22.12 \%)$ and digestible energy content (11.81 $\left.\mathrm{MJ} \mathrm{kg}^{-1}\right)$. Five iso-nitrogenous (30\%) and iso-caloric diets $\left(13.5 \mathrm{MJ} \mathrm{kg}^{-1}\right)$ were prepared by replacing DORB with sweet potato leaf meal (SPLM) at $0 \%(\mathrm{C}), 25 \%$ (T1), 50\% (T2), 75\% (T3) and $100 \%$ (T4). Each dietary treatment was tested in triplicates with 12 fingerlings per tank, following completely randomised design. The growth performance and feed utilisation parameters viz., weight gain \% (WG), specific growth rate (SGR), protein efficiency ratio (PER) and feed conversion ratio (FCR) were not significantly different $(\mathrm{p}>0.05)$ among treatments. The digestive enzyme activity remained unaffected except amylase activity, which increased significantly in 50\% SPLM replacement group (T2). Chymotrypsin decreased significantly $(\mathrm{p}<0.05)$ in the treatment groups. Metabolic enzymes viz., ATPase activity of liver increased significantly $(\mathrm{p}<0.05)$ whereas ALP (alkaline phosphatase) activity in the intestine had irregular pattern. The present study indicates that DORB can be completely replaced by SPLM without affecting growth performance and digestive enzyme activity in the diet of $L$. rohita.
\end{abstract}

Keywords: Body composition, De-oiled rice bran, Growth performance, Labeo rohita, Sweet potato leaf meal

\section{Introduction}

Aquaculture is a rapidly growing food-producing sector. For sustainable fish production, use of formulated feed is of utmost importance. Aquaculture in India is slowly shifting from non-feed based or extensive culture systems to feed based semi-intensive culture systems. Artificial feeding is one of the most important factor required for faster growth and higher yield for fish culture (Jose et al., 2006; Maity and Patra, 2008). The feed ingredients have to be sourced mainly from plants, agriculture products and animal protein. Plant-based alternative ingredients are widely available and many are already being used for aqua feed. The long-term viability of aquaculture will only be realised if use of alternative and non-conventional ingredients are promoted to use in place of conventional ingredients.

De-oiled rice bran (DORB) is the most commonly utilised agricultural byproducts used in feed formulation (Kumar et al., 2017: 2018a,b; 2019; Ranjan et al., 2018a,b; 2019). As a source of carbohydrate, it provides energy in the diet and also offers a substantial part of the essential amino acids (Tsvetanov and Duneva, 1990; Ranjan et al., 2017; 2018a). Even in farm-made feed, major part is contributed by the rice bran (50-80\%) along with other agricultural byproducts. The importance of dietary and functional properties of rice bran has led to its multiple uses including human consumption (Sharif, 2009) and so the demand for rice bran has grown exponentially. Further, yield losses in rice production due to climate change related issues became another determinant of price of rice bran. The cumulative effects of these multiple factors have forced the price of rice bran to surge up to ₹14-19 $\mathrm{kg}^{-1}$ in Indian markets creating huge stress on aquafeed production. Hence, an alternative source of rice bran has been investigated here. Many reports on use of various sources of leaf meal proteins in diet of herbivorous and carnivorous fishes viz., cassava leaf meal $(\mathrm{Ng}$ and Wee, 1989), alfalfa (Yousif et al., 1994), Carica papaya (Reyes and Fermin, 2003) and Leucaena leucocephala (Bairagi et al., 2004). These studies projected leaf meal as a good source to replace protein and energy sources in fish feed. There are many inexpensive, unutilised leafy plants whose nutritive and anti-nutritive potentials are yet to be sufficiently studied and exploited, among which sweet potato leaves deserve a special attention 
(Antia et al., 2006). Sweet potato is a widely grown crop in tropical countries but originated from Central America. The crude protein and crude fibre contents of the foliage of sweet potato differ largely with variety, soil and water condition and parts of the plant. According to Preston (2006), the crude protein content of leaves varied from 26.5 to $32.5 \%$ on dry matter basis. Sweet potato leaves (SPL) are used as vegetables, especially in China and South-east Asia. Moreover, being used for human consumption, the SPL serves as fodder for cattle, sheep, goats, pigs and other domestic animals (Antia et al., 2006). There are very few reports available on the use of sweet potato leaves in fish feed. The foliage production of sweet potato can be from 4.3 to $6.0 \mathrm{t} \mathrm{DM} \mathrm{ha}^{-1} \mathrm{crop}^{-1}$ (Ruiz et al., 1981). It can be planted twice in a year because it has a short generation interval hence it can be harvested many times throughout the year (Hong et al., 2003). The price calculated at farm site is around ₹ 10 per $\mathrm{kg}$ and dry weight recovery was around $20 \%$ depending on the maturity stages of leaf. The shrubbery parts of sweet potato, such as leaves, stalks and stems have a high nutritive value (Ishida et al., 2000). In particular, leaves contain a large amount of protein with a high amino acid score. Contents of minerals and vitamins such as $\mathrm{A}, \mathrm{B}_{2}, \mathrm{C}$ and $\mathrm{E}$ are high in leaves in comparison to other vegetables. Presence of anti-nutritional factor is the major limiting factor of sweet potato leaf meal utilisation as feed ingredients. SPLM has been reported to contain various anti-nutritional factors like invertase, protease inhibitors, cyanide, tannins, oxalate and phytate (Tacon, 1993; Antia et al., 2006). Sweet potato leaves are deficient in some essential amino acids like lysine, necessitating the inclusion of adequate lysine in diets (Fuller and Chamberlain, 1982). Since there is limited information available on the utilisation of sweet potato leaf meal as an energy source in the diet of rohu Labeo rohita (Hamilton, 1822), the present study was conducted to evaluate the potential of sweet potato leaf meal as a replacer of DORB in the diet.

\section{Materials and methods}

\section{Preparation of sweet potato leaf meal (SPLM)}

Sweet potato leaves were collected from the Doab region of Ganga basin near Patna from a local farm. The leaves were washed, dried in shade and brought to the lab and again dried in the oven at $40^{\circ} \mathrm{C}$ for a night and dried leaf was ground and screened using $50 \mathrm{~mm}$ mesh.

\section{Experimental set up}

Rohu fingerlings were procured from Nisarga fish farm, Boiser, Thane, Mumbai, Maharashtra. The fishes were transported to the wet laboratory of ICAR-Central Institute of Fisheries Education (ICAR-CIFE), Mumbai in oxygen filled polyethylene bags. Two hundred fifty fishes were carefully transferred to a circular tank (500 1) and were left undisturbed overnight. In order to reduce handling stress, the fishes were given a vitamin $\mathrm{C}$ (1 $\mathrm{mg} \mathrm{l}^{-1}$ ) treatment and on the subsequent day salt treatment $\left(20 \mathrm{~g} \mathrm{l}^{-1}\right)$ was given to eliminate chances of parasitic infection. The fingelings were acclimatised under aerated conditions for a period of 30 days. During acclimation, fish were fed with a basal diet containing $30 \%$ crude protein. One hundred eighty fingerlings with an average size of $4.3 \pm 0.2 \mathrm{~g}$ were randomly distributed in 15 rectangular plastic tanks following completely randomised design (CRD). The experiment was conducted for a period of 60 days. Five iso-caloric $\left(13.5 \mathrm{MJ} \mathrm{kg}^{-1}\right)$ and iso-nitrogenous ( $30 \%$ crude protein) experimental diets were prepared (Table 1). Fishes were fed twice daily at $2 \%$ body weight at 10:00 hrs in the morning and in the evening at 16:00 hrs. Sufficient aeration was provided in all tanks. Siphoning was done daily to remove the excreta and residual feed. The same volume of water was replenished after siphoning.

Table 1. Proximate composition of sweet potato leaf meal (SPLM) and de-oiled rice bran (DORB)

\begin{tabular}{lll}
\hline Parameters & SPLM & DORB \\
\hline Dry matter & $95.57 \pm 5.00$ & $91.93 \pm 0.60$ \\
Crude protein & $22.12 \pm 3.00$ & $15.03 \pm 0.50$ \\
Crude fat & $3.59 \pm 1.50$ & $0.57 \pm 0.18$ \\
Crude fiber & $15.43 \pm 2.00$ & $14.47 \pm 0.23$ \\
Nitrogen free extract & $38.40 \pm 3.30$ & $55.89 \pm 0.36$ \\
Ash content & $16.03 \pm 6.50$ & $6.07 \pm 0.61$ \\
\hline
\end{tabular}

Values are Mean $\pm \operatorname{SE}(\mathrm{n}=3)$

The ingredient composition of different experimental diet is presented in Table 2. Practical ingredients such as groundnut oil cake, de-oiled rice bran, wheat flour, carboxymethyl cellulose (CMC), defatted soyabean meal, butylated hydroxytoluene (BHT), cod liver oil, vitamin and mineral mixture, were used for feed preparation. Six iso-caloric and iso-nitrogenous diets were prepared with $30 \%$ protein. All the ingredients were weighed according to the formulation, cooked in pressure cooker, cooled, vitamins and mineral mixture were added, pressed through a pelletizer and dried. After drying, the pellets were packed in polythene bags and were sealed airtight and were labelled according to the treatments.

\section{Water quality parameters}

Water quality parameters viz., temperature, dissolved oxygen, ammonia, total hardness, $\mathrm{pH}$, ammonia, nitrite- $\mathrm{N}$ and nitrate- $\mathrm{N}$ were determined as per the standard methods of APHA (1998). 
Table 2. Ingredients composition of experimental diets

\begin{tabular}{llllll}
\hline Ingredients & $\mathrm{C}$ & $\mathrm{T} 1$ & $\mathrm{~T} 2$ & $\mathrm{~T} 3$ & $\mathrm{~T} 4$ \\
\hline GNOC $^{\mathrm{a}}$ & 30 & 28 & 26 & 26 & 26 \\
SPLM $^{\mathrm{b}}$ & 0 & 7.5 & 15 & 22.5 & 30 \\
DORB $^{\mathrm{c}}$ & 30 & 22.5 & 15 & 7.5 & 0 \\
DSBM $^{\mathrm{d}}$ & 20 & 20 & 20 & 19 & 19 \\
Wheat flour $^{\mathrm{e}}$ & 9.35 & 11.35 & 13.35 & 14.3 & 14.8 \\
Fish meal $^{\mathrm{e}}$ & 5 & 5 & 5 & 5 & 4.5 \\
Fish oil $^{\mathrm{e}}$ & 3 & 3 & 3 & 3 & 3 \\
Vit-min mix $^{\mathrm{f}}$ & 2 & 2 & 2 & 2 & 2 \\
Vit C $^{\mathrm{g}}$ & 1.0 & 1.0 & 1.0 & 1.0 & 1.0 \\
BHT $^{\mathrm{g}}$ & 0.05 & 0.05 & 0.05 & 0.05 & 0.05 \\
CMC $^{\mathrm{g}}$ & 0.5 & 0.5 & 0.5 & 0.5 & 0.5 \\
\hline
\end{tabular}

T: Treatment; C: Control; CMC: Carboxymethyl cellulose; BHT: Butylated hydroxyl toluene; ${ }^{a} \mathrm{GNOC}$ : Groundnut oil cake; ${ }^{\mathrm{b} S P L M}$ : sweet potato leaf meal; 'DORB: De-oiled rice bran; ${ }^{\mathrm{D} D S B M}$ : Defatted soybean meal;

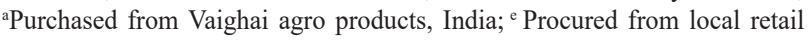
shop.

${ }^{\mathrm{f}}$ Composition of vitamin mineral mix (PREEMIX PLUS) (quantity per kg): Vitamin A - 55,00,000 IU; Vitamin $\mathrm{D}_{3}$ - 11,00,000 IU; Vitamin B - 2,000 mg; Vitamin E - 50 mg; Vitamin K - 1,000 mg; Vitamin $B_{6}-1,000$ mg; Vitamin $\mathrm{B}_{12}-6 \mu \mathrm{g}$; Calcium pantothenate - 2,500 mg; Nicotinamide - $10 \mathrm{~g}$; Choline chloride - $150 \mathrm{~g} ; \mathrm{Mn}-27,000 \mathrm{mg} ; \mathrm{I}-1,000 \mathrm{mg}$; Fe - 7,500 mg; Zn - 5,000 mg; $\mathrm{Cu}-2,000 \mathrm{mg}$; Co - 450 L-lysine - $10 \mathrm{~g}$; DL-Methionine - $10 \mathrm{~g}$; Selenium ${ }^{\mathrm{g}}$ Purified ingredients procured from HiMedia Ltd., India

\section{Proximate analysis of leaf, diet and whole fish}

Proximate analysis of the DORB, SPLM and experimental diets, was done by following standard methods (AOAC, 1995). Similarly, body composition of experimental fishes was estimated following AOAC method (1995). Moisture content of the experimental diets was determined by taking a known weight of the sample in a petridish and drying it in a hot air oven at $100-105^{\circ} \mathrm{C}$ till a constant weight was achieved. Crude protein content was determined by micro-Kjeldahl method (Kelplus, PELICAN, India). Fat content of experimental diets samples were estimated by soxhlet apparatus using diethyl ether (boiling point $65 \pm 5^{\circ} \mathrm{C}$ ) as the solvent. Ash content of the experimental diets was estimated by taking a known weight of dried samples in a silica crucible and placing it in a muffle furnace at $600^{\circ} \mathrm{C}$ for 5-6 h. Fibre estimation was done in Fibre Tech (Tulin Equipment, India) apparatus and further ashing was done using a muffle furnace at $550^{\circ} \mathrm{C}$ for $5 \mathrm{~h}$. Nitrogen free extract of the experimental diets was calculated by subtracting the percentage of other nutrients from 100:

NFE $(\%)=100-[$ Crude protein $(\%)+$ Ether extract $(\%)+$ Ash $(\%)+$ Fibre $(\%)]$

\section{Growth performance and nutrient utilisation}

The growth assessment of experimental fish were done fortnightly by estimation of growth parameters and nutrient utilisation parameters using following formulae:

\author{
Weight gain $\%$ \\ $=[$ Final weight - Initial weight $/$ \\ Initial weight $] \times 100$ \\ Specific growth rate $(\mathrm{SGR}) \quad=\left[\left(\log _{e}\right.\right.$ Final weight $-\log _{e}$ Initial \\ weight)/Number of days] $\times 100$ \\ Feed conversation ratio $(\mathrm{FCR})=[$ Feed consumed $(\mathrm{g}$, on dry \\ weight basis)/Body gain (g, on \\ wet weight basis)] \\ Feed efficiency ratio (FER) $\quad=[$ Body gain $(\mathrm{g}$ on wet weight \\ basis/Feed consumed ( $\mathrm{g}$ on dry \\ weight basis)] \\ Protein efficiency ratio (PER) $=[$ Net weight gain $(\mathrm{g}$ on wet \\ weight basis)/ Protein fed ( $\mathrm{g}$ on \\ dry weight basis)] \\ Hepatosomatic index (HSI) $=[$ Wet weight of liver $(\mathrm{g}) /$ Wet \\ weight to fish $(\mathrm{g})] \times 100$ \\ Intestinal somatic index (ISI) $=[$ Weight of intestine $(\mathrm{g}) /$ Weight \\ of fish] $\times 100$
}

Enzyme assay

Sample preparation

On termination of the experiment, three fishes from each tank were randomly collected and anesthetised with clove oil $\left(50 \mu \mathrm{l} \mathrm{l}^{-1}\right)$. Fishes were then dissected and the tissues viz., liver, intestine and muscle, were immediately excised. A 5\% tissue homogenate was prepared in chilled $0.25 \mathrm{M}$ sucrose solution using a teflon coated mechanical homogenizer (REMI, Mumbai, India). The whole procedure was carried out in ice-cold condition. Homogenised samples were centrifuged at $6000 \mathrm{rpm}$ for $10 \mathrm{~min}$ at $4^{\circ} \mathrm{C}$. The supernatant was collected in glass vials and stored in a deep freezer $\left(-20^{\circ} \mathrm{C}\right)$ for enzyme assay. Total protein of each tissue sample for enzyme assays was estimated by the Bradford method (Bradford, 1976).

Digestive enzymes assay

Protease activity was determined by the casein digestion method (Drapeau, 1976). Trypsin and chymotrypsin activity were estimated as per the methods described by Kunitz et al. (1947). Amylase activity was estimated as the reducing sugars produced due to the action of glucoamylase following di-nitro-salicylic-acid (DNS) method (Rick and Stegbauer, 1974). Specific amylase activity was expressed as the mole of maltose released from starch per min at $37^{\circ} \mathrm{C}$ temperature. The lipase activity was determined following the procedure of Cherry and Crandall (1932). The reaction mixture was prepared with distilled water, tissue homogenate, phosphate buffer ( $\mathrm{pH} 7$ ) and olive oil emulsion. The whole mixture was shaken well and incubated at $37^{\circ} \mathrm{C}$ for $24 \mathrm{~h}$, After adding 95\% alcohol and 2 drops of phenolphthalein indicator, titrated against $0.05 \mathrm{~N} \mathrm{NaOH}$ until it exhibited 
a permanent pink colour. The milli-equivalent of alkali consumed was taken as a measure of the activity of the enzyme unit $\mathrm{mg}^{-1}$ protein.

Alkaline phosphatase (ALP) assay

The alkaline phosphatase (ALP) activity was determined by the method of Garen and Levinthal (1960). The assay mixture comprised $0.2 \mathrm{ml}$ bicarbonate buffer $(0.2 \mathrm{~m}), 0.1 \mathrm{ml}$ of $0.1 \mathrm{M} \mathrm{MgCl}_{2}, 0.1 \mathrm{ml}$ tissue homogenate, $0.5 \mathrm{ml}$ of distilled water and $0.1 \mathrm{ml}$ freshly prepared $0.1 \mathrm{M}$ para-nitrophenyl phosphate. The reaction mixture was incubated in a water bath at $37^{\circ} \mathrm{C}$ for $15 \mathrm{~min}$ and the reaction was stopped by adding $1.0 \mathrm{ml}$ of $0.1 \mathrm{~N} \mathrm{NaOH}$ and OD was measured at $410 \mathrm{~nm}$.

\section{Adenosine triphosphate diphosphohydrolase (ATPase)} assay

ATPase (Adenosine triphosphate diphosphohydrolase, E.C. 3.6.1.3) was assayed in a reaction mixture of $0.1 \mathrm{M}$ Tris- $\mathrm{HCl}$ buffer (pH 7.8), $100 \mathrm{mM} \mathrm{NaCl}, 20 \mathrm{mM} \mathrm{KCl}$, $3 \mathrm{mM} \mathrm{MgCl}$ and $5 \mathrm{mM}$ ATP. The mixture was incubated for $15 \mathrm{~min}$ and then the reaction was terminated by means of 10\% trichloroacetic acid (Post and Sen, 1967). Phosphate liberated was estimated at $660 \mathrm{~nm}$ (Fiske and Subbarow, 1925).

\section{Statistical analysis}

The data was subjected to one-way analysis of variance (ANOVA) using SPSS 16.0 for Windows. Duncan's multiple range test was performed for post hoc comparison of means between different experimental groups. All data presented are means \pm standard error and statistical significance for all statistical tests was set at $\mathrm{p}<0.05$.

\section{Results and discussion}

The water quality parameters such as temperature (27.3-29.5 $\left.{ }^{0} \mathrm{C}\right)$, dissolved oxygen $\left(6-6.9 \mathrm{mg} \mathrm{l}^{-1}\right)$, ammonia (0.13-0.20 $\left.\mathrm{mg} \mathrm{l}^{-1}\right)$, total hardness $\left(229-246 \mathrm{mg} \mathrm{l}^{-1}\right)$, $\mathrm{pH}$ (7.2-8.5), nitrite-N (0.001-0.002 $\left.\mathrm{mg} \mathrm{l}^{-1}\right)$, nitrate-N (0.03-0.04 $\left.\mathrm{mg} \mathrm{l}^{-1}\right)$ recorded during the experimental period were found to be within the optimum range for fish.

The proximate composition of SPLM and DORB are presented in Table 1. As compared to DORB, SPLM contains more crude protein and crude fat. However, SPLM contains more crude fibre and total ash content. The proximate composition of experimental diets is presented in Table 3. The proximate composition of whole body of L. rohita is presented in Table 4 . The body composition of L. rohita viz., moisture content, dry matter, crude protein, lipid, carbohydrate and ash content did not vary significantly $(\mathrm{p}>0.05)$.

Feed cost represents the highest operating cost in aquaculture, ranging from 30 to $60 \%$ of the operating cost based on the culture system (Riaz, 1997). The cost of feed can be reduced by using low cost ingredients. The evaluation of ingredient is based on nutritional composition and its effect on growth performance of fish. The proximate composition (\%) of sweet potato (Ipomoea batatas) leaves showed that ash, crude fat, crude protein, crude fibre and nitrogen-free extract content were lower than the values reported by

Table 3. Proximate composition of experimental diets

\begin{tabular}{llllc}
\hline Ingredients & $\mathrm{C}$ & $\mathrm{T} 1$ & $\mathrm{~T} 2$ & $\mathrm{~T} 3$ \\
\hline Dry matter & $90.96 \pm 0.76$ & $91.12 \pm 0.19$ & $89.90 \pm 0.62$ & $90.89 \pm 0.15$ \\
Crude protein & $31.05 \pm 0.06$ & $30.57 \pm 0.02$ & $30.95 \pm 0.07$ & $30.63 \pm 0.16$ \\
Crude lipid & $5.89 \pm 0.83$ & $5.95 \pm 0.96$ & $5.00 \pm 0.37$ & $5.84 \pm 0.58$ \\
Ash & $9.26 \pm 0.64$ & $8.73 \pm 0.44$ & $9.35 \pm 0.67$ & $8.49 \pm 0.55$ \\
Dietary fiber & $8.95 \pm 0.34$ & $9.18 \pm 0.86$ & $8.34 \pm 0.02$ & $9.70 \pm 0.08$ \\
NFE & $33.78 \pm 0.36$ & $36.66 \pm 0.50$ & $34.24 \pm 0.22$ & $36.21 \pm 0.45$ \\
Energy(MJ kg-1) & $13.58 \pm 0.83$ & $13.64 \pm 0.12$ & $13.25 \pm 0.44$ & $13.69 \pm 0.01$ \\
\hline
\end{tabular}

C: Control; T: Treatments; NFE: Nitrogen free extract, Calculated energy* $\left(\mathrm{MJ} \mathrm{kg}^{-1}\right)=\left[16.749 \mathrm{CP}\left(\mathrm{g} \mathrm{kg}^{-1}\right)+37.79 \mathrm{EE}\left(\mathrm{g} \mathrm{kg}^{-1}\right)+16.749 \mathrm{TC}\left(\mathrm{g} \mathrm{kg}{ }^{-1}\right)\right] / 1000$

Table 4. Proximate composition of whole body of $L$. rohita fingerlings of different experimental groups (\% wet weight basis)

\begin{tabular}{llllll}
\hline Treatment & Moisture & Dry matter & Crude protein & Lipid & Carbohydrate \\
\hline Control & $76.93 \pm 0.42$ & $23.06 \pm 0.73$ & $14.84 \pm 0.49$ & $2.34 \pm 0.29$ & $2 . .21 \pm 0.26$ \\
T1 & $77.09 \pm 0.46$ & $22.90 \pm 0.80$ & $14.95 \pm 0.16$ & $2.70 \pm 0.24$ & $3.24 \pm 0.43$ \\
T2 & $77.33 \pm 0.42$ & $22.67 \pm 0.74$ & $14.97 \pm 0.73$ & $2.90 \pm 0.09$ & $2.29 \pm 0.97$ \\
T3 & $76.94 \pm 0.74$ & $23.06 \pm 1.28$ & $13.91 \pm 0.65$ & $2.69 \pm 0.08$ & $3.13 \pm 0.39$ \\
T4 & $76.92 \pm 0.49$ & $23.67 \pm 0.86$ & $15.34 \pm 0.35$ & $2.78 \pm 0.34$ & $1.84 \pm 0.22$ \\
p value & $>0.05$ & $>0.05$ & $>0.05$ & $>0.05$ & $3.65 \pm 0.66$ \\
\hline
\end{tabular}

All values are expressed as Mean $\pm \operatorname{SE}(n=3)$ 
Hong et al. (2003), Akindahunsi and Salawu (2005) and Etuk et al. (2009). However, protein content recorded during the present study was similar to that reported by Oduro et al. (2008), but less than that observed by Antia et al. (2006). It may be due to the difference in variety as reported by Ishida et al. (2000), who found significant differences in protein content among the cultivars. The high ash content $(16.03 \pm 0.65)$ in the SPLM is a reflection of the high mineral contents. The results, therefore suggest a high deposit of mineral elements in the leaves.

There was no significant effect of dietary DORB replacement by SPLM on the tissue protein level and in the lipid level of the fish. This is supported by the findings of Muin et al. (2013) who reported that the replacement of rice bran with Pleurotus florida stalks has no significant impact on body composition of Clarias gariepinus fingerlings. In the present study these values were within the normal range for L. rohita, which was in agreement with Adewolu et al. (2008) who reported that SPLM did not cause any significant change in the body composition of Tilapia zilli fingerlings.

The nutritional quality of sweet potato leaf meal in rohu was determined in terms of body weight gain (WG $\%$ ), specific growth rate (SGR), feed conversion ratio (FCR) and protein efficiency ratio (PER). The growth and nutrient utilisation parameters viz., WG(\%), SGR, FCR and PER are presented in Table 4. The weight gain percentage, SGR, FCR and PER did not vary significantly $(\mathrm{p}>0.05)$ among the various treatment groups (Table 4). However, these parameters were not significantly different $(p>0.05)$ from fish fed with SPLM compared to the control diet (0\% leaf meal). Meshram et al. (2018) reported similar results when incorporation of fermented sweet potato leaf meal in the fish diet was replaced by de-oiled rice bran in the diet of $L$. rohita. In the present study, the inclusion of sweet potato leaf meal at levels up to $100 \%$ replacement of rice bran did not reduce the growth rate and feed utilisation of $L$. rohita fingerlings and no significant difference in FCR was observed in fish fed with different levels of SPLM. Fasakin et al. (1999) reported that up to 30\% inclusion, in the diet, duckweed (Spirodela polyrrhiza) supported favourable growth in Oreochromis niloticus. The HSI and ISI were found similar among different treatments $(\mathrm{p}>0.05)$ (Table 5).

Breakdown of macro nutrients into micro absorbable monomeric forms in the digestive tract of the animals depends largely on the accessible enzymes (Blier et al., 2002). Ingredient source and type can alter the secretion of enzyme and its activity from the digestive tract. For better growth performance, digestive and metabolic capacity to support the tissue protein synthesis is required (Blier et al., 2002), because the digestive enzymes play a key role in nutrient utilisation and growth performance of fish (Chan et al., 2008, Kumar et al., 2017). The breakdown of nutrients depends on the digestive enzymes activity associated with better digestion and absorption of nutrients (Kumar et al., 2018b). The activity of digestive enzymes like protease, trypsin and lipase in the intestine of $L$. rohita juveniles were found similar ( $p>0.05$ ) among different experimental groups (Table 6). The chymotrypsin activity in the intestine was significantly $(p<0.05)$ higher in the control group (C) and lower in T3 and T4 groups. Amylase activity significantly varied among different groups and the highest amylase activity in the intestine was recorded in the $\mathrm{T} 2$ group $(\mathrm{p}<0.05)$. Reduced protein digestibility may be associated with phytate and trypsin inhibitors present in SPLM (Antia et al., 2006). Trypsin inhibitor inhibits the activity of protein-digesting enzymes (Ali et al., 2009) and phytate forms complexes with minerals (Sugiura et al., 1999) and proteins (Moyano et al., 1999). In the present study, no significant growth depression was observed for sixty days of feeding trial. This observation was in corroboration with the findings of Krogdahl et al. (1994) and Santigosa et al. (2008) in trout.

Similarly, ALP activity of the liver varied significantly among treatment groups and the lowest ALP activity was observed in control group $(\mathrm{p}<0.05)$. No significant difference was observed in lipase, protease and trypsin activities when compared with the control, but it was observed that the group fed with higher levels of SPLM had significantly lower $(\mathrm{p}<0.05)$ chymotrypsin, ALP and amylase activity, which could be attributed to the presence

Table 5. Growth parameters of $L$. rohita fingerlings fed with different experimental diets at the end of the experiment

\begin{tabular}{llllllllll}
\hline Treatments & Initial weight (g) & Final weight $(\mathrm{g})$ & WG $(\%)$ & SGR & FCR & PER & HSI (\%) & ISI (\%) & Survival (\%) \\
\hline Control & $4.30 \pm 0.03$ & $8.06 \pm 0.55$ & $100.58 \pm 5.01$ & $1.11 \pm 0.11$ & $2.01 \pm 0.29$ & $1.65 \pm 0.28$ & $0.77 \pm 0.05$ & $3.18 \pm 0.26$ & 98 \\
T1 & $4.42 \pm 0.02$ & $8.30 \pm 0.44$ & $97.90 \pm 4.09$ & $1.12 \pm 0.11$ & $2.50 \pm 0.13$ & $1.29 \pm 0.06$ & $0.90 \pm 0.11$ & $3.30 \pm 0.25$ & 100 \\
T2 & $4.41 \pm 0.09$ & $9.09 \pm 0.24$ & $106.31 \pm 5.02$ & $1.29 \pm 0.06$ & $2.39 \pm 0.14$ & $1.32 \pm 0.07$ & $0.75 \pm 0.05$ & $4.10 \pm 0.32$ & 95 \\
T3 & $4.49 \pm 0.07$ & $9.14 \pm 0.38$ & $103.72 \pm 5.03$ & $1.26 \pm 0.07$ & $2.41 \pm 0.18$ & $1.36 \pm 0.11$ & $0.92 \pm 0.16$ & $3.93 \pm 0.15$ & 95 \\
T4 & $4.49 \pm 0.03$ & $8.56 \pm 0.21$ & $90.42 \pm 4.45$ & $1.29 \pm 0.04$ & $2.74 \pm 0.13$ & $1.14 \pm 0.05$ & $1.04 \pm 0.12$ & $3.51 \pm 0.36$ & 99 \\
p value & $>0.05$ & $>0.05$ & $>0.05$ & $>0.05$ & $>0.05$ & $>0.05$ & $>0.05$ & $>0.05$ & $>0.05$ \\
\hline
\end{tabular}

WG: Weight gain; SGR:Specific growth rate; FCR: Feed conversion ratio; FER: Feed efficiency ratio; PER: Protein efficiency ratio; HSI: Hepatosomatic Index ISI: Intestinal somatic Index. Values are Mean $\pm \mathrm{SE}(\mathrm{n}=9)$, Mean values in the same column with different superscripts differ significantly $(\mathrm{p}<0.05)$ 
Table 6. Specific enzyme activities in the digestive tract of $L$. rohita fingerlings fed with different replacement level of DORB with the SPLM

\begin{tabular}{|c|c|c|c|c|c|c|c|c|c|}
\hline \multirow{2}{*}{ Treatments } & \multirow{2}{*}{$\begin{array}{l}\text { Protease } \\
\text { (Intestine) }\end{array}$} & \multirow{2}{*}{$\begin{array}{l}\text { Trypsin } \\
\text { (Intestine) }\end{array}$} & \multirow{2}{*}{$\begin{array}{l}\text { Chymotrypsin } \\
\text { (Intestine) }\end{array}$} & \multirow{2}{*}{$\begin{array}{l}\text { Amylase } \\
\text { (Intestine) }\end{array}$} & \multirow{2}{*}{$\begin{array}{l}\text { Lipase } \\
\text { (Intestine) }\end{array}$} & \multicolumn{2}{|c|}{ ATPase } & \multicolumn{2}{|c|}{ ALP } \\
\hline & & & & & & Liver & Intestine & Intestine & Liver \\
\hline $\mathrm{C}$ & $41.06 \pm 3.2$ & $1.49 \pm 0.29$ & $0.74^{\mathrm{c}} \pm 0.06$ & $1.96^{\mathrm{ab}} \pm 0.17$ & $0.66 \pm 0.09$ & $1.53^{\mathrm{a}} \pm 0.36$ & $12.22 \pm 1.2$ & $107.60^{c} \pm 5.66$ & $10.26^{\mathrm{a}} \pm 1.28$ \\
\hline $\mathrm{T} 1$ & $26.65 \pm 3.3$ & $0.73 \pm 0.16$ & $0.49^{b} \pm 0.09$ & $1.46^{\mathrm{a}} \pm 0.24$ & $0.72 \pm 0.09$ & $1.45^{\mathrm{a}} \pm 0.14$ & $18.05 \pm 2.6$ & $61.65^{\mathrm{ab}} \pm 6.69$ & $15.25^{\mathrm{c}} \pm 3.64$ \\
\hline $\mathrm{T} 2$ & $27.47 \pm 5.2$ & $1.21 \pm 0.14$ & $0.50^{b} \pm 0.08$ & $2.57^{\mathrm{b}} \pm 0.32$ & $0.62 \pm 0.07$ & $1.37^{\mathrm{ab}} \pm 0.29$ & $21.56 \pm 0.86$ & $75.78^{b} \pm 5.65$ & $14.37^{\mathrm{c}} \pm 1.64$ \\
\hline T3 & $27.61 \pm 5.9$ & $0.87 \pm 0.26$ & $0.25^{\mathrm{a}} \pm 0.03$ & $1.80^{\mathrm{a}} \pm 0.17$ & $0.80 \pm 0.07$ & $2.47^{b} \pm 0.37$ & $18.11 \pm 2.6$ & $46.22^{\mathrm{a}} \pm 2.88$ & $11.24^{b} \pm 2.22$ \\
\hline $\mathrm{T} 4$ & $26.13 \pm 4.7$ & $0.51 \pm 0.13$ & $0.38^{\mathrm{ab}} \pm 0.02$ & $1.65^{\mathrm{a}} \pm 0.24$ & $0.76 \pm 0.11$ & $2.58^{\mathrm{b}} \pm 0.27$ & $19.22 \pm 2.8$ & $58.43^{\mathrm{a}} \pm 5.73$ & $10.72^{b} \pm 1.16$ \\
\hline $\mathrm{p}$ value & $>0.05$ & $>0.05$ & $<0.05$ & $<0.05$ & $>0.05$ & $<0.05$ & $>0.05$ & $<0.05$ & $<0.05$ \\
\hline
\end{tabular}

Activities are expressed as follows: Protease as micromole of tyrosine released per min per mg protein; Amylase as micromole unit per min per mg protein; Lipase activity as units per hour per mg protein; Alkaline phosphatase (ALP) as Nano moles p-nitrophenol released per min per mg protein at $37^{\circ} \mathrm{C}$. Different superscript letters in the same column signify statistical differences $(\mathrm{p}<0.05)$. Data expressed as Mean $\pm \mathrm{SE}(\mathrm{n}=6)$

of trypsin inhibitors and other anti-nutritional factors associated with SPLM. ALP activity of the intestine was observed to decrease with the increasing SPLM inclusion level in the diet and highest activity was observed in the control group $(\mathrm{p}<0.05)$ followed by $\mathrm{T} 2, \mathrm{~T} 1, \mathrm{~T} 3$ and T4 group. Alkaline phosphatase activity plays a major role in the phosphorus metabolism in the body. It catalyses the hydrolysis of various phosphate-containing compounds and acts as transphosphorylase at alkaline $\mathrm{pH}$. This enzyme gets activated during the energy demand and the presence of excess levels of phosphorus in the diet. In the present study, the ALP activity in intestine and liver varied significantly. The deficiency of sodium can have an impact on the activity of Na-K-ATPase in the gastrointestinal (GI) tract and liver, which is involved in the absorption of nutrients. It has been reported that ingestion of phytic acid reduced the activity of Na-K-ATPase in the GI tract and liver in broilers (Liu et al., 2008), whcih may be one of the reasons for the increase in the liver ATPase activity in SPLM fed groups which resulted in a reduction of phytic acid with replacement of rice bran in the diet. Replacement of DORB with SPLM significantly $(p<0.05)$ affected ATPase activity in the liver of $L$. rohita juveniles in different experimental groups. However, ATPase activity in the intestine did not differ significantly among groups.

Based on the finding of the present study, it is concluded that SPLM can replace $100 \%$ of de-oiled rice bran in practical diets of $L$. rohita. Further, agro wastes like sweet potato leaves based feeds are cheaper as compared to the conventional feeds. However, the economic viability of incorporation of SPLM in L. rohita diets as a replacer of DORB needs to be studied. The present study advocates short-term utilisation efficiency but same time indicated the inevitability of long-term feeding trial with SPLM by replacing DORB and its effect on the physiology of fish. In addition to this, dietary utilisation of detoxified SPLM as a replacer of DORB can also be taken up as an approach for cost-effective use of SPLM as agriculture waste in aqua feed.

\section{Acknowledgements}

The authors are thankful to the Indian Council of Agriculture Research (ICAR), New Delhi and the Director and Vice-Chancellor, ICAR-CIFE, Mumbai, India, for providing all the facilities required for the present work.

\section{References}

Adewolu, M. A. 2008. Potentials of sweet potato (Ipomoea batatas) leaf meal as the dietary ingredient for Tilapia zilli fingerlings. Pak. J. Nutr., 7(3): 444-449. DOI: 10.3923/ pjn.2008.444.449.

Akindahunsi, A. A. and Salawu, S. O. 2005. Phytochemical screening and nutrient-anti nutrient composition of selected tropical green leafy vegetables. Afr. J. Biotechnol., 4: 497-501.

Ali, H., Haque, M. M., Chowdhury, M. M. R. and Shariful, M. I. 2009. In vitro protein digestibility of different feed ingredients in Thai koi (Anabas testudineus). J. Bangladesh Agric. Univ., 7(1): 205-210. DOI: 10.3329/jbau.v7i1.4985.

Antia, S., Akpan, E. J., Okon, P. A. and Umoren, I. U. 2006. Nutritive and anti-nutritive evaluation of sweet potato (Ipomoea batatas) leaves. Pak. J. Nutr., 5(2): 166-168. DOI: $10.3923 /$ pjn.2006.166.168.

AOAC 1995. Official methods of analysis, $16^{\text {th }}$ edn. Cunniff, P. (Ed.), Association of Official Analytical Chemists, Arlington, USA.

APHA-AWWA-WEF 1998. Standard methods for the examination of water and wastewater, $20^{\text {th }}$ edn. American Public Health Association, American Water Works Association, Water Environment Federation, Washington DC, USA.

Bairagi, A., Ghash, K. S., Sen, S. K. and Ray, A. K. 2004. Evaluation of the nutritive value of Leucaena leucocephala leaf meal, inoculated with fish intestinal bacteria Bacillus subtilis and Bacillus circulans in formulated diets for rohu, Labeo rohita fingerlings. Aquac. Res., 35: 436-446. doi.org/10.1111/j.1365-2109.2004.01028.x.

Blier, P. U., Lemieux, H. and Devlin, R. H. 2002. Is the growth rate of fish set by digestive enzymes or metabolic 
capacity of the tissues? Insight from transgenic coho salmon. Aquaculture, 209(1): 379-384.

Bradford, M. M. 1976. A rapid and sensitive method for the quantitation of microgram quantities of protein utilising the principle of protein-dye binding. Ann. Biochem., 72(1-2): 248-254. doi.org/10.1016/0003-2697(76)90527-3.

Chan, C. R., Lee, D. N., Cheng, Y. H., Hsieh, D. J. Y. and Weng, C. F. 2008. Feed deprivation and re-feeding on alterations of proteases in tilapia Oreochromis mossambicus. Zool. Stud., 47: 207-214.

Cherry, I. S. and Crandall, L. A. 1932. The specificity of pancreatic lipase: its appearance in the blood after pancreatic injury. Am. J. Physiol. Legacy Content, 100(2): 266-273. doi.org/10.1152/ajplegacy. 1932.100.2.266.

Drapeau, G. R. 1976. Protease from Staphyloccus aureus. Method Enzymol., 45: 469-475. doi.org/10.1016/S0076-6879(76) 45041-3.

Etuk, E. U., Agaie, B. M., Ladan, M. J. and Garba, I. 2009. The modulatory effect of Cochlospermum tinctorium a rich aqueous root extract on liver damage induced by carbon tetrachloride in rats. Afr. J. Pharmacol., 3(4): 151-157.

Fasakin, E. A., Balogun, A. M. and Fasuru, B. E. 1999. Use of duckweed, Spirodela polyrrhiza Schieiden, as a protein feedstuff in practical diets for tilapia (Oreochromics niloticus). Aquac. Res., 30: 313-318. doi.org/10.1046/ j.1365-2109.1999.00318.x.

Fiske, C. H. and Subbarow, Y. 1925. The colorimetric determination of phosphorus. J. Biol. Chem., 66(2): 375-400.

Fuller, M. F. and Chamberlain, A. G. 1982. Protein requirements of pigs. In: Haresign, W. (Ed.), Recent advances in animal nutrition, Butterworths, London, p. 175-186.

Garen, A. and Levinthal, C. 1960. A fine-structure genetic and chemical study of the enzyme alkaline phosphatase of E. coli I. Purification and characterisation of alkaline phosphatase. Biochim. Biophys. Acta, 38: 470-483. doi.org/10.1016/0006-3002(60)91282-8.

Hong, N. T. T., Wanapat, M., Wachirapakorn, C., Pakdee, P. and Rowlinson, P. 2003. Effects of timing of initial cutting and subsequent cutting on yields and chemical compositions of cassava hay and its supplementation on lactating dairy cows. Asian Austral. J. Anim. Sci., 16(12): 1763-1769.

Ishida, H., Suzuno, H., Sugiyama, N., Innami, S., Tadokoro, T. and Maekawa, A. 2000. Nutritive evaluation on chemical components of leaves, stalks and stems of sweet potatoes (Ipomoea batatas Poir). Food Chem., 68(3): 359-367. DOI : 10.1016/S0308-8146(99)00206-X.

Jose, S., Mohan, M. V., Shyama, S., Ramachandran Nair, K. G. and Mathew, P. T. 2006. Effect of soybean meal based diets on the growth and survival rate of the Indian major carp, Cirrhinus mrigala (Ham.). Aquac. Nutr., 12(4): 275-279. doi.org/10.1111/j.1365-2095.2006.00405.x.
Krogdahl, A., Lea, T. B. and Olli, J. J. 1994. Soybean proteinase inhibitors affect intestinal trypsin activities and amino acid digestibilities in rainbow trout (Oncorhynchus mykiss). Comp. Biochem. Physiol. Part A: Physiol., 107(1): 215-219. https://doi.org/10.1016/0300-9629(94)90296-8.

Kumar, S., Sahu, N. P., Gupta, S., Deo, A. D., Shamna, N. and Ranjan, A. 2017. Inclusion level of deoiled rice bran (DORB) in the diet of Labeo rohita (Hamilton, 1882) fingerlings: Effect on growth and gene expression of IGF $\square$ I and IGF $\square I I$. Aquaculture, 481: 211-217. https://doi org/10.1016/j.aquaculture.2017.08.025.

Kumar, S., Sahu, N. P. and Ranjan, A. 2018a. Feeding de $\sqsubset$ oiled rice bran (DORB) to Rohu, Labeo rohita: Effect of varying dietary protein and lipid level on growth, body composition and insulin like growth factor (IGF) expression. Aquaculture, 492: 59-66. https://doi.org/10.1016/j. aquaculture.2018.04.001.

Kumar, S., Sahu, N. P., Shamna, N. and Ranjan, A. 2018b. Feeding higher level of de $\square$ oiled rice bran causes stress to Labeo rohita fingerlings. Aquaculture, 484: 184-190. https://doi.org/10.1016/j.aquaculture.2017.11.029.

Kumar, S., Sahu, N. P., Deo, A. D. and Ranjan, A. 2019. Feeding de $\square$ oiled rice bran based diet with varying levels of protein and lipid: Effect on physiological responses of Labeo rohita. Aquaculture, 498: 454-463.

Kunitz, M. 1947. Crystalline soybean trypsin inhibitor II. General properties. J. Gen. Physiol., 30(4): 291-310.

Liu, N., Ru, Y. J., Li, F. D. and Cowieson, A. J. 2008. Effect of diet containing phytate and phytase on the activity and messenger ribonucleic acid expression of carbohydrase and transporter in chickens. J. Ani. Sci., 86(12): 34323439. doi: $10.2527 /$ jas.2008-1234.

Maity, J. and Patra, B. C. 2008. Effect of replacement of fishmeal by Azolla leaf meal on growth, food utilisation, pancreatic protease activity and RNA/DNA ratio in the fingerlings of Labeo rohita (Ham.). Can. J. Pure Appl. Sci., 2(2): 323

Meshram, S., Deo, A. D., Kumar, S., Aklakur, M. and Sahu, N. P. 2018. Replacement of deoiled rice bran by soaked and fermented sweet potato leaf meal: effect on growth performance, body composition and expression of insulinlike growth factor 1 in Labeo rohita (Hamilton), fingerlings. Aquac. Res., 49(8): 2741-2750. https://doi.org/10.1111/ are. 13735 .

Moyano, F. J., Martnez, I., Daz, M. and Alarcon, F. J. 1999. Inhibition of digestive proteases by vegetable meals in three fish species; seabream (Sparus aurata), tilapia (Oreochromis niloticus) and African sole (Solea senegalensis). Comp. Biochem. Physiol.Part B: Biochem. Molecul. Biol., 122(3): 327-332. DOI10.1016/S03050491(99)00024-3.

Muin, T. A. I. H., Fatah, N. N. A., Bahari, I. H. and Razak, S. A. 2013. Rice bran replacement in Clarias gariepinus fingerlings diets with Pleurotus florida stalk. Sains Malaysiana, 42(8): 1109-1114. 
Ng, W. K. and Wee, K. L. 1989. The nutritive value of cassava leaf meal in pelleted feed for Nile tilapia. Aquaculture, 83(1-2): 45-58. https://doi.org/10.1016/0044-8486(89)90059-8.

Oduro, I., Ellis, W. O. and Owusu, D. 2008. Nutritional potential of two leafy vegetables: Moringa oleifera and Ipomoea batatas leaves. Scien. Res. Essays, 3(2): 57-60.

Post, R. L. and Sen, A. K. 1967. Sodium and potassiumstimulated ATPase. In: Estabrook, R. W. and Pullman, M. E. (Eds.), Methods in enzymology, vol. X. Oxidation and phosphorylation. Academic Press, New York and London, p. $762-768$.

Preston, T. R. 2006. Forages as protein sources for pigs in the tropics. . CAB Rev. : Perspectives in Agriculture, Veterinary Science, Nutrition and Natural Resources, 1(046): p. 1-10. https://www.cabdirect.org/cabdirect/abstract/200 63204173 (Accessed 5 August 2018).

Ranjan, A., Sahu, N. P., Deo, A. D., Kumar, H. S., Kumar, S. and Jain, K. K. 2017. Xylanase and phytase supplementation in the De-oiled rice bran (DORB) based diet improves the growth performance of Labeo rohita. Inter. J. Curr. Microbiol. Appl. Sci., 6(6): 1493-1503. http://dx.doi. org/10.20546/ijcmas.2017.606.176.

Ranjan, A., Sahu, N. P., Deo, A. D., Kumar, H. S., Kumar, S. and Jain, K. K. 2018a. Comparative evaluation of fermented and non-fermented de-oiled rice bran with or without exogenous enzymes supplementation in the diet of Labeo rohita (Hamilton, 1822). Fish Physol. Biochem., 44(4): 1037-1049. doi: 10.1007/s10695-018-0492-2.

Ranjan, A., Sahu, N. P., Deo, A. D. and Kumar, S. 2018b. Comparative growth performance, in vivo digestibility and enzyme activities of Labeo rohita fed with DORB based formulated diet and commercial carp feed. Turk. J. Fish. Aquatic Sci., 18(9): 1025-1036. DOI: 10.4194/1303-2712v18_9_02.

Ranjan, A., Sahu, N. P., Deo, A. D. and Kumar, S. 2019. Solid state fermentation of de-oiled rice bran: Effect on in vitro protein digestibility, fatty acid profile and anti-nutritional factors. Food Res. Int., 119: 1-5.
Reyes, O. S. and Fermin, A. C. 2003. Terrestrial leaf meals or freshwater aquatic fern as potential feed ingredients for farmed abalone Haliotis asinine. Aquac. Res., 34: 593-599. https://doi.org/10.1046/j.1365-2109.2003.00846.x.

Riaz, M. N. 1997. Aquafeed to optimise water quality. Feed Int., 18(3): 22-28.

Rick, W. and Stegbauer, H. P. 1974. $\alpha$ - Amylase measurement of reducing groups. Methods of enzymatic analysis, 2: 885-889.

Ruiz, M. E., Lozano, E. and Ruiz, A. 1981. Utilisation of sweet potatoes [Ipomoea batata (L.) Lam] in animal feeding. III. Addition of various levels of roots and urea to sweet potato forage silages. Trop. Anim. Prod., 6(3): 234-244.

Santigosa, E., Sanchez, J., Medale, F., Kaushik, S., PerezSanchez, J. and Gallardo, M. A. 2008. Modifications of digestive enzymes in trout (Oncorhynchus mykiss) and sea bream (Sparus aurata) in response to dietary fish meal replacement by plant protein sources. Aquaculture, 282: 68-74. https://doi.org/10.1016/j.aquaculture.2008.06.007.

Sharif, M. K. 2009. Rice industrial byproducts management for oil extraction and value added products, $\mathrm{Ph}$. D. thesis, University of Agriculture, Faisalabad, Pakisthan.

Sugiura, S. H., Raboy. V., Young, K. A., Dong, F. M. and Hardy, R. W. 1999. Availability of phosphorus and trace elements in low-phytate varieties of barley and corn for rainbow trout (Oncorhynchus mykiss). Aquaculture, 170(3): 285-296. DOI: 10.1016/S0044-8486(98)00414-1.

Tacon, A. G. J. 1993. Feed ingredients for warm water fish and other processed feed stuffs, FAO Fisheries Circular No. 856, Food and Agriculture Organisation, Rome, 64: 1-17.

Tsvetanov, I. M. and Duneva, N. 1990. Study on the substitution of maize with rice bran and incineration fat in mixed feeds for broiler chickens. Zhivotnovdni Nauki, 27: 42-50.

Yousif, O. M., Alhadhrami, G. A. and Passaraki, M. 1994. Evaluation of dehydrated alfalfa and Saltbush Atriplex leaves in diets for Tilapia (Oreochromis aureus). Aquaculture, 126: 341-347. https://doi.org/10.1016/0044-8486(94)90050-7. 